\title{
Prevalence and Severity of Symptoms of Asthma, Allergic Rhinoconjunctivitis, and Atopic Eczema in 6- to 7-Year-Old Nigerian Primary School Children: The International Study of Asthma and Allergies in Childhood
}

\author{
A.G. Falade ${ }^{a}$ J.F. Olawuyi ${ }^{\text {b }}$ K. Osinusi ${ }^{a} \quad$ B.O. Onadeko ${ }^{c}$ \\ Departments of aPaediatrics, ${ }^{\mathrm{b}}$ Biostatistics and Epidemiology, and ${ }^{\mathrm{c}}$ Medicine, Faculty of Clinical Sciences and \\ Dentistry, College of Medicine, University of Ibadan, Ibadan, Nigeria
}

\section{Key Words}

Prevalence $\cdot$ Severity $\cdot$ Asthma Allergic rhinoconjunctivitis - Eczema - Nigerian children • International Study of Asthma and Allergies in Childhood

\begin{abstract}
Objective: To determine the prevalence and severity of symptoms of asthma, allergic rhinoconjunctivitis and eczema in Nigerian children aged 6-7 years. Subjects and Methods: A cross-sectional study of selected children in primary schools in Ibadan, Nigeria was conducted using phase I of the International Study of Asthma and Allergies in Childhood (ISAAC) format. Standardized questionnaires were distributed to parents and guardians of 2,325 children aged 6-7 years in 31 primary schools randomly selected among 272 in Ibadan. $\boldsymbol{R e}$ sults: Data was collected from 1,704 children (797 boys and 907 girls; M:F ratio 1:1.14), giving a participation rate of $73.3 \%$. Both recent rhinoconjunctivitis and wheeze were reported by $5.1 \%$, and itchy flexural rash in the past 12 months was reported by $8.5 \%$. The cumulative prevalences of reported symptoms of wheezing, rhinitis and eczema were $7.2,11.3$ and $10.1 \%$, respectively. These symptoms were basically the same among the boys and
\end{abstract}

\section{KARGER}

Fax +41613061234

E-Mail karger@karger.ch

www.karger.com

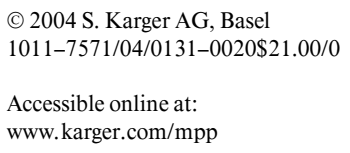

girls (rhinitis 11.4 vs. $11.2 \%$; eczema 10.7 vs. $9.5 \%$ ), except for wheezing, which was higher in boys $(9.0 \%)$ than girls $(5.6 \%), p=0.015$. Current symptoms of rhinitis and atopic eczema were associated with current wheeze and severe wheezing, whereas current symptoms of allergic rhinoconjunctivitis were only associated with severe wheezing attacks. One or more current symptoms occurred in $13.2 \%$ of the children, and all three symptoms were reported by $0.5 \%$. Conclusion: The study demonstrates a high prevalence of atopic conditions among children 6-7 years old in Ibadan, Nigeria, with more than three fifths of the children who had current wheezing also showing symptoms of other atopic diseases. Children with allergic rhinoconjunctivitis were more likely to have severe wheezing attacks if they had developed atopic eczema before 2 years of age.

Copyright $@ 2004$ S. Karger AG, Basel

\section{Introduction}

Bronchial asthma is one of the most common chronic illnesses afflicting the paediatric age group [1]. Despite advances in knowledge about the pathophysiology of asthma and the availability of potent drugs for the treatment of the disease, morbidity and mortality show no evidence 
of decline [2]. Similarly, the prevalence of other allergic diseases such as allergic rhinoconjunctivitis and eczema has also been increasing in western and developing countries [3-7]. However, variation in the prevalence of these atopic diseases has been reported and might be due to differences in definition or in the study methodology used to evaluate the epidemiology of these diseases. Therefore, standardized written and video questionnaires have been developed in phase I of the International Study of Asthma and Allergies in Childhood (ISAAC), which could provide insight into the risk factors responsible for the rising trend in asthma and other atopic diseases [2].

The ISAAC phase I study involved two age groups: children 6-7 years old and adolescents 13-14 years old. The aims were to describe the prevalence and severity of asthma, allergic rhinitis and eczema in children living in different places and to make comparisons within and between countries; to obtain baseline measures for assessing future trends in the prevalence and severity of these diseases, and to provide a framework for further aetiological research into socioeconomic, environmental, and genetic factors affecting these diseases.

The goal of the present study, which is part of a global initiative and the only one in Africa until now, was to determine the prevalence and severity of symptoms of asthma, allergic rhinoconjunctivitis and eczema in children aged 6-7 years in Ibadan, Nigeria, using the ISAAC protocol.

\section{Subjects and Methods}

This cross-sectional study was carried out from January 1 to May 31,1995 on children 6-7 years old in primary schools in Ibadan, Nigeria, one of the most densely populated cities in Africa, with an estimated population of 4 million [8].

\section{Sampling Method}

For the study, 31 primary schools were randomly selected from a total of 272 primary schools in Ibadan, and 2,325 children aged 6-7 years were selected from grades 1 and 2 for participation in the study. The ages of the children were ascertained from the class registers. Questionnaires were distributed to the children, who took them home for their parents or guardians to complete, then returned them to their teachers.

\section{Questionnaire}

The ISAAC collaborators agreed that the cardinal symptom of asthma would be variable narrowing of the airways and best described as 'wheezing or whistling in the chest'. The questionnaire incorporated sensitive (although not necessarily specific) questions for asthma and more specific questions related to the severity of asthma [9]. In recent years a number of studies have compared responses to the ISAAC core wheezing questions with other indicators of asth- ma, including physician diagnosis, other questionnaires and physiological measures, and indicate that the ISAAC questionnaire has a level of sensitivity and specificity that is acceptable for the purposes of international comparisons [9].

It was considered appropriate to use the English version of the ISAAC written questionnaires [9] since English is the official language in Nigeria, and the literacy rate among the parents or guardians completing questionnaires was $77 \%$ in females and $87 \%$ in males [8]. Where illiterate parents or guardians were involved, a literate relative completed the questionnaire. Briefly, the questionnaire has four sections: demographic data, 8 questions on wheezing and asthma, 6 questions on rhinitis, and 7 questions on eczema. The questionnaire concentrated on past and current wheezing episodes, wheezing frequency, sleep disturbances and speech limitations during attacks, exercise-induced wheezing, night cough unrelated to common cold, and a doctor's diagnosis of asthma. In addition, ISAAC core questions were included regarding the presence and severity of eczema and allergic rhinitis, which is the term used in Nigeria to indicate hay fever.

\section{Prevalence Rates}

The prevalence of symptoms was calculated by dividing the number of positive responses to each question by the number of completed questionnaires. The proportions of children with symptoms of asthma, allergic rhinoconjunctivitis or atopic eczema were determined. The overall 12-month prevalence of one or more symptoms of asthma, allergic rhinoconjunctivitis or atopic eczema was calculated.

\section{Ethical Consideration}

Informed consent to carry out the study was obtained from the head teachers of the primary schools, the parents or guardians of the children, and the Oyo State Ministry of Education and Youth Development, Ibadan, Nigeria. The study received institutional approval from the Joint University of Ibadan/University College Hospital, Ethical Committee.

\section{Statistical Analysis}

The data were analysed using the Epi-Info (version 6) software. Estimates of odds ratios (ORs), standard errors and 95\% confidence intervals (95\% CIs) were based on asymptomatic likelihood theory. Categorical variables were compared using chi square $\left(\chi^{2}\right)$ test. Factors associated with current wheeze and severe wheezing were determined by the use of multiple stepwise logistic regressions. A $p$ value less than 0.05 was considered to be significant.

\section{Results}

\section{Participating Schools, Response Rates and Sample Size}

Of the 2,325 questionnaires distributed to the schoolchildren aged 6-7 years, a total of 1,704 forms were completed (797 boys and 907 girls; M:F ratio 1:1.14), giving a participation rate of $73.3 \%$. Missing values for any one question are variable. Therefore, denominators for prevalence vary from one category of symptom to another. 
Table 1. Parent-reported prevalence of symptoms of asthma, allergic rhinitis and eczema among 6- to 7-year-olds using ISAAC written questionnaire
Table 2. Parent-reported prevalence of symptoms indicating severity of symptoms of asthma, allergic rhinitis and eczema

\begin{tabular}{|c|c|c|c|}
\hline Symptoms & $\begin{array}{l}\text { Boys } \\
\text { n (\%) }\end{array}$ & $\begin{array}{l}\text { Girls } \\
\text { n (\%) }\end{array}$ & $\begin{array}{l}\text { Total } \\
\text { n (\%) }\end{array}$ \\
\hline Responses for asthma $(n=1,704)$ & $797(46.8)^{\mathrm{a}}$ & $907(53.2)^{\mathrm{a}}$ & $1,704(100)^{\mathrm{a}}$ \\
\hline Ever wheezed & $72(9.0)$ & $51(5.6)$ & $123 \quad(7.2)$ \\
\hline Wheeze in the last 12 months & $50(6.3)$ & $37(4.1)$ & $(5.1)$ \\
\hline Wheezing with exercise in the last 12 months & $50 \quad(6.3)$ & $9(3.2)$ & $(4.6)$ \\
\hline Night cough in the last 12 months & $59(7.4)$ & $51(5.6)$ & $(6.5)$ \\
\hline Ever diagnosed asthma & $32(4.0)$ & $20 \quad(2.2)$ & $(3.1)$ \\
\hline Responses for rhinitis $(n=1,648)$ & $844(51.2)^{\mathrm{a}}$ & $804(48.8)^{\mathrm{a}}$ & $1,648(100)^{\mathrm{a}}$ \\
\hline Ever had rhinitis & $96(11.4)$ & $90(11.2)$ & $186(11.3)$ \\
\hline Rhinitis in the last 12 months & $85(10.1)$ & $86(10.7)$ & $171(10.4)$ \\
\hline Associated itchy eye last 12 months & $40 \quad(4.7)$ & $44 \quad(5.5)$ & $84 \quad(5.1)$ \\
\hline Ever diagnosed allergic rhinitis & $80 \quad(9.5)$ & $90(11.2)$ & $170(10.3)$ \\
\hline Responses for eczema $(n=1,312)$ & $671(51.1)^{\mathrm{a}}$ & $641(48.9)^{\mathrm{a}}$ & $1,312(100)^{\mathrm{a}}$ \\
\hline Itchy rash ever & $72(10.7)$ & $61(9.5)$ & $133(10.1)$ \\
\hline Itchy rash in the last 12 months & $66 \quad(9.8)$ & $54 \quad(8.4)$ & $120 \quad(9.1)$ \\
\hline Atopic eczema (flexural itchy rash) & $61(9.1)$ & $50 \quad(7.8)$ & $(8.5)$ \\
\hline \multicolumn{4}{|l|}{ Age at onset of itchy rash } \\
\hline$<2$ years & $40 \quad(6.0)$ & $43(6.7)$ & $(6.3)$ \\
\hline $2-4$ years & $19(2.8)$ & $9(1.4)$ & $(2.1)$ \\
\hline$\geq 5$ years & 13 (1.9) & 9 (1.4) & (1.7) \\
\hline Ever diagnosed eczema & $69(10.3)$ & $45 \quad(7.0)$ & $(8.7)$ \\
\hline
\end{tabular}

a Indicates percentages relative to the total number of responses.

\begin{tabular}{|c|c|c|c|c|}
\hline Symptoms & $\begin{array}{l}\text { Boys } \\
\text { n (\%) }\end{array}$ & $\begin{array}{l}\text { Girls } \\
\text { n (\%) }\end{array}$ & $\begin{array}{l}\text { Total } \\
\text { n (\%) }\end{array}$ & \\
\hline Responses for asthma $(n=1,704)$ & \multirow[t]{2}{*}{$797(46.8)^{\mathrm{a}}$} & \multirow[t]{2}{*}{$907(53.2)^{\mathrm{a}}$} & \multicolumn{2}{|c|}{$1,704(100)^{\mathrm{a}}$} \\
\hline \multicolumn{3}{|l|}{ Number of wheezing episodes } & & \\
\hline $1-3$ & $33(4.1)$ & $21(21.3)$ & 54 & $(3.2)$ \\
\hline$\geq 4$ & $17(2.1)$ & $16(1.8)$ & 33 & $(1.9)$ \\
\hline \multicolumn{5}{|l|}{ Woken by wheeze } \\
\hline Never & $4(0.5)$ & $2(0.2)$ & 6 & $(0.3)$ \\
\hline$<1$ per week & $26 \quad(3.3)$ & $18 \quad(2.0)$ & 44 & $(2.6)$ \\
\hline$\geq 1$ per week & $20(2.5)$ & $17(1.9)$ & 37 & $(2.2)$ \\
\hline Speech limitation during wheezing attack & $36 \quad(4.5)$ & $28 \quad(3.1)$ & 64 & (3.7) \\
\hline Responses for rhinitis $(n=1,648)$ & $844(51.2)^{\mathrm{a}}$ & $804(48.8)^{\mathrm{a}}$ & 1,648 & $100)^{\mathrm{a}}$ \\
\hline \multicolumn{5}{|l|}{ Interferes with daily activity } \\
\hline Not at all & $24 \quad(2.8)$ & 21 & 45 & (2.7) \\
\hline Little & $27(3.2)$ & $24(3.0)$ & 51 & $(3.1)$ \\
\hline Moderate & $23(2.7)$ & $28 \quad(2.7)$ & 45 & $(2.7)$ \\
\hline A lot & $11(1.3)$ & $19(2.4)$ & 30 & $(1.8)$ \\
\hline \multirow{3}{*}{$\begin{array}{l}\text { Responses for eczema }(n=1,312) \\
\text { Persistent rash without clearing } \\
\quad \text { (severe eczema) }\end{array}$} & $671(51.1)^{\mathrm{a}}$ & $641(48.9)^{\mathrm{a}}$ & \multicolumn{2}{|c|}{$1,312(100)^{\mathrm{a}}$} \\
\hline & & & & \\
\hline & $29(4.3)$ & $26(4.1)$ & 55 & $(4.2)$ \\
\hline \multicolumn{5}{|l|}{ Kept awake by itchy rash } \\
\hline Never & $14(2.1)$ & $2(0.3)$ & 16 & $(1.2)$ \\
\hline$<1$ per week & $33 \quad(4.9)$ & $35 \quad(5.5)$ & 68 & $(5.2)$ \\
\hline$\geq 1$ per week & $19(2.8)$ & $17 \quad(2.6)$ & 36 & $(2.7)$ \\
\hline
\end{tabular}




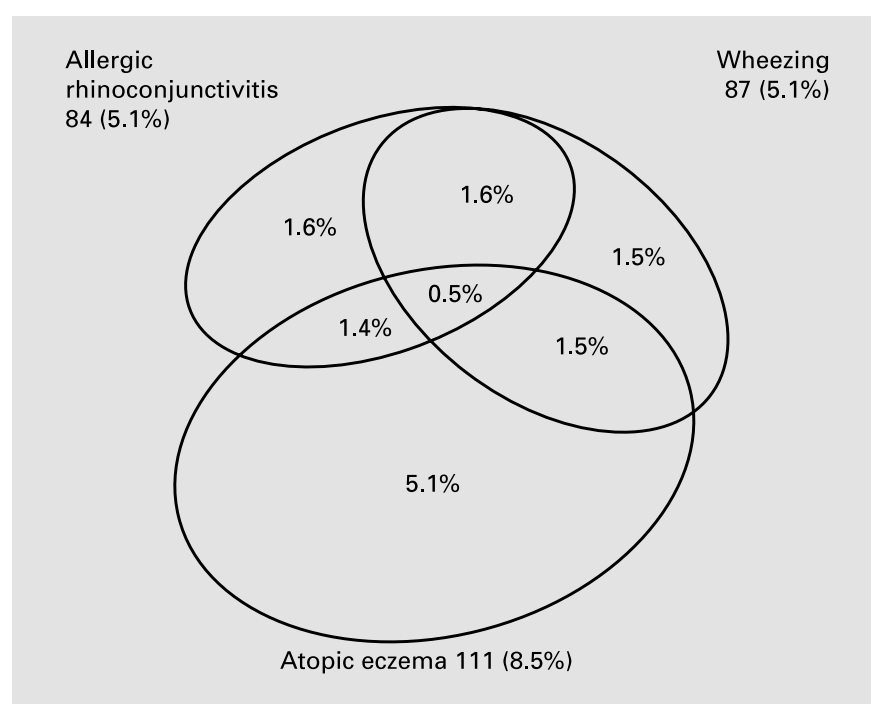

Fig. 1. Prevalence of parent-reported symptoms of asthma and other atopic diseases within the past 12 months in children 6-7 years old at Ibadan in 1995.

\section{Prevalence Rates}

The overall cumulative and current prevalence of parent-reported symptoms of asthma, allergic rhinitis and eczema are summarized in table 1 . The cumulative prevalences of reported symptoms of wheezing, rhinitis and eczema were $7.2,11.3$ and $10.1 \%$, respectively. These symptoms were basically the same among boys and girls (rhinitis ever: 11.4 vs. $11.2, \mathrm{p}=0.979$; eczema ever: 10.7 vs. $9.5 \%, p=0.571)$, but wheezing was significantly different: boys $9.0 \%$ and girls $5.6 \%(\mathrm{p}=0.015)$.

The prevalence of symptoms of asthma, allergic rhinitis, and atopic eczema as reported by the parents and guardians for the 12-month period was 5.1, 5.1 and 8.5\%, respectively. Allergic rhinitis was the most commonly diagnosed allergic disorder, with $10.3 \%(170 / 1,648)$ of the parents/guardians reporting the diagnosis. The prevalence of doctor-diagnosed eczema $(8.7 \%)$ was similar, but doctor-diagnosed asthma was only $3.1 \%$ as compared to $5.1 \%$ reported by parents.

Figure 1 illustrates the interrelationship between parent-reported current symptoms of atopic eczema, allergic rhinoconjunctivitis, and wheeze. Of the $5.1 \%$ reporting current wheezing, $29.9 \%$ (26 of 87), 34.5\% (30 of 87) and $70.1 \%$ (61 of 87) had current symptoms of atopic eczema, allergic rhinoconjunctivitis, and current symptoms of other atopic diseases.

Children with 1, 2 or 3 symptoms of wheeze, rhinoconjunctivitis, or itchy flexural rash were reported by $8.2,4.5$, and $0.5 \%$ of children's parents, respectively. Atopic ecze-

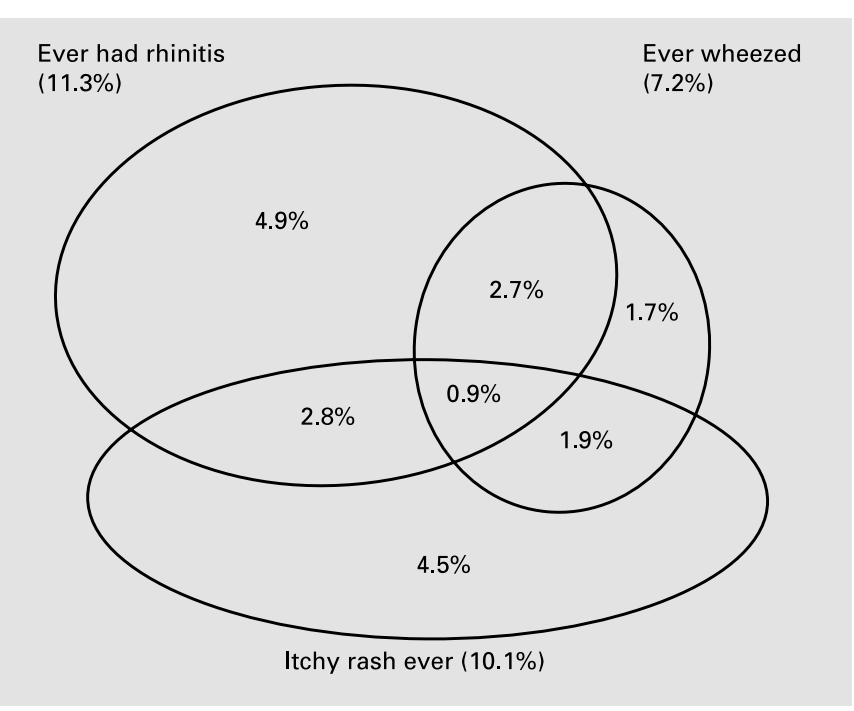

Fig. 2. Lifetime prevalence of parent-reported symptoms of asthma and other atopic diseases in children 6-7 years old at Ibadan in 1995.

ma was the most commonly reported current symptom, affecting $8.5 \%$.

Figure 2 shows a Venn diagram, demonstrating the overlap between reported lifetime occurrence of itchy rash (eczema), rhinitis, and asthma. Of the $7.2 \%$ with a diagnosis of asthma, 30.1\% (37 of 123), 20.3\% (25 of 123 ), $10.6 \%$ (13 of 123 ), and $61 \%$ (75 of 123 ) had associated rhinitis, itchy rash, rhinitis plus itchy rash, and other atopic diseases, respectively.

Overall, it was reported that $19.4 \%$ of the children ever had one or more of the atopic diseases. Of these, 11.1, 7.4, and $0.9 \%$ of the children's parents reported ever having 1 , 2 , or all 3 of the atopic diseases, respectively. In contrast to current symptoms, prevalences of lifetime eczema (10.1\%) and rhinitis other than common cold (11.3\%) were similar, and more common than the cumulative prevalence of wheezing (7.2\%).

\section{Severity of Symptoms}

Table 2 describes the severity of current symptoms of asthma, allergic rhinitis, and eczema. Only $1.9 \%$ had 4 or more wheezing episodes in 12 months, and allergic rhinitis was reported to interfere a lot with daily activity in $1.8 \%$ of the children. Severe eczema was reported by $4.2 \%$ of the study population.

Risk Factors for Current Wheeze and Severe Wheezing Risk factors associated with current wheeze and severe wheezing as determined by multiple stepwise logistic 
Table 3. Risk factors for current wheeze and severe wheeze limiting speech in the past 12 months by multiple stepwise logistic regression

\begin{tabular}{|c|c|c|c|c|}
\hline Parameters & $\begin{array}{l}\text { Current wheeze } \\
\text { OR }(95 \% \mathrm{CI})\end{array}$ & $\mathrm{p}$ value & $\begin{array}{l}\text { Severe attack } \\
\text { OR }(95 \% \text { CI })\end{array}$ & $\mathrm{p}$ value \\
\hline \multicolumn{5}{|l|}{ Sex } \\
\hline Female & 1.54 & 0.07 & 1.21 & 0.72 \\
\hline Male & $(0.97-2.43)$ & & $(0.58-2.53)$ & \\
\hline \multicolumn{5}{|c|}{ Rhinitis in the last 12 months } \\
\hline Yes & 2.15 & 0.00 & 5.86 & 0.00 \\
\hline No & $(1.63-2.84)$ & & $(3.96-8.73)$ & \\
\hline \multicolumn{5}{|c|}{ Associated itchy eye last 12 months } \\
\hline Yes & 1.00 & 0.95 & 2.72 & 0.00 \\
\hline No & $(0.73-1.37)$ & & $(1.78-4.18)$ & \\
\hline \multicolumn{5}{|c|}{ Itchy flexural rash in past year } \\
\hline Yes & 1.72 & 0.00 & 4.68 & 0.00 \\
\hline No & $(1.27-2.32)$ & & $(3.10-7.09)$ & \\
\hline \multicolumn{5}{|c|}{ Age of onset of itchy rash } \\
\hline$<2$ years & 0.09 & 0.00 & 0.03 & 0.00 \\
\hline$\geq 2$ years & $(0.06-0.14)$ & & $(0.02-0.06)$ & \\
\hline
\end{tabular}

regressions are shown in table 3 . There was no sex predilection for report of current wheeze (OR, $1.54 ; 95 \% \mathrm{CI}$, $0.97-2.43 ; \mathrm{p}=0.065)$ or severe attack $(\mathrm{OR}, 1.21 ; 95 \% \mathrm{CI}$, $0.58-2.53 ; p=0.71)$. The presence of both current rhinitis and current eczema was associated with current wheeze and severe wheezing attack. History of allergic rhinoconjunctivitis in the last 12 months did not constitute a risk factor for current wheeze, but it was associated with severe wheezing attack. Children who experienced atopic eczema at younger than 2 years of age were more likely to have current wheeze or severe wheezing attack.

\section{Discussion}

Using parent-completed ISAAC questionnaires, we were able to show that symptoms of asthma, allergic rhinoconjunctivitis and atopic eczema were common among a group of primary schoolchildren aged 6-7 years in Ibadan, Nigeria. Reliability of a parent-completed questionnaire in determining the prevalence of these symptoms had been questioned, but previous studies have shown that a history of wheezing, rhinitis with associated itchy eye, and itchy flexural rash, which can be readily observed by parents, is reasonably sensitive for diagnosing bronchial hyperresponsiveness [10], allergic rhinitis [11], and atopic eczema, respectively.
When taken together with data on the prevalence of wheeze and atopic symptoms among children in developing countries with diverse environmental conditions, the findings in this study have been extremely useful in understanding the aetiology of these diseases. For instance, in this study the cumulative prevalence of wheezing $(7.2 \%)$ and the 12 -month prevalence $(5.1 \%)$ are comparable to those found in other developing countries like Mexico, Malaysia, Hong Kong, Taiwan, Iran, Oman, and India, as well as many developed non-English-speaking countries of Europe [12]. But the prevalence of wheezing in the United Kingdom (UK) and other English-speaking developed countries (Australia, New Zealand, United States of America) is much higher at 18.4 and $>20 \%$, respectively [12]. This difference might reflect differences in environmental factors, such as varying pollution levels or different dietary habits. It has been suggested that increased hygiene and healthcare in western countries has altered the pattern of exposure to infection in early life in such a way as to predispose the immune system towards the atopic response [13]. Western hygienic habits and semisterile diet may influence the overall pattern of commensals and pathogens that stimulate the lymphoid tissue in the gut, thus contributing to the epidemic of allergic asthma and rhinitis in developed countries [14]. In addition, ecological analyses of ISAAC data for children 6-7 years old and 13-14 years old using the dietary data based on 1995 Food and Agriculture Organization of the United Nations for 53 of the 56 countries that took part in ISAAC phase I (1994/1995) have shown a consistent inverse relationship between the prevalence rates of the three conditions (symptoms of asthma, allergic rhinoconjunctivitis and atopic eczema) and the intake of starch, cereals, and vegetables [15], which are a staple diet in developing countries.

Among the children in Ibadan, the prevalence of nocturnal cough for the 12 -month period $(6.5 \%)$ was higher than that of wheezing $(5.1 \%)$ or doctor-diagnosed asthma $(3.1 \%)$. The question concerning whether the child had ever had 'asthma' probably indicates the level of perceived or diagnosed asthma [12], and it has been reported that it is a highly reliable measure for epidemiological purposes [16]. While the prevalence of current rhinitis (10.4\%) was higher than that of allergic rhinitis (5.1\%), which is distinguished from acute coryza by the presence of itchy and watering eyes, similar prevalence rates of allergic rhinitis have been observed in Sweden (5.9\%), Portugal (5.0\%), Malaysia (5.0\%), and France (5.9\%) [17]. 
The prevalence of atopic eczema (8.5\%) in this study could be described as moderately high $(5-10 \%)$, and is comparable to the prevalence values in some countries of Asia-Pacific (Malaysia, Philippines, South Korea), and South America (Argentina, Brazil). However, this flexural rash in Nigeria is different from that in Europe $[18,19]$ because other itchy dermatoses such as scabies are common [20].

As shown in table 3, our findings that asthma and wheeze developed more often in those with perennial rhinitis (current rhinitis) than in subjects with allergic rhinitis are consistent with those of Linna et al. [21]. Those who have current atopic eczema and experienced onset of atopic eczema before the age of 2 years were more likely to develop current wheeze and have severe wheeze. Knowledge of the environmental factors that influence the development of atopic eczema may offer the greatest opportunities for prevention of asthma and the amelioration of its severe symptoms.

\section{Conclusion}

The results demonstrate a high prevalence of atopic conditions among children 6-7 years old in Ibadan, Nigeria. More than three fifths of the children with current wheezing also had current symptoms of other atopic diseases. Furthermore, children with allergic rhinoconjunctivitis who developed atopic eczema before 2 years of age were more likely to have severe wheezing attacks. This underscores the importance of atopic disease in Nigerian children, both singly and in combination with wheezy illness and asthma.

\section{Acknowledgements}

We are grateful to Chief Bode Akindele and Dr. Raymond Zard, management of Glaxo Wellcome, Nigeria, for financial support. The secretarial assistance of Mrs. O.F. Adegoke and Mrs. A.O. Ayoade is appreciated.

\section{References}

1 Evans R 3rd, Mullaly DI, Wilson RW, Gergen PJ, Rosenberg HM, Grauman JS, Chevarley FM, Feinleib M: National trends in the morbidity and mortality of asthma in the US: Prevalence, hospitalization and deaths from asthma over two decades: 1965-1984. Chest 1987; 91(suppl): 65S-74S

2 Buist AS, Vollmer WM: Reflection on the rise in asthma morbidity and mortality. JAMA 1990;264:1719-1720.

3 Taylor B, Wadsworth J, Wadsworth M, Peckham $\mathrm{C}$ : Changes in the reported prevalence of childhood eczema since the 1939-45 war. Lancet 1984;ii:1255-1257.

4 Burr ML, Butland BK, King S, Vaughan-Williams E: Changes in asthma prevalence: Two surveys 15 years apart. Arch Dis Child 1989; 64:1452-1456.

5 Omran M, Russell G: Continuing increase in respiratory symptoms and atopy in Aberdeen school children. BMJ 1996;312:34.

6 Ninan TK, Russell G: Respiratory symptoms and atopy in Aberdeen school children: Evidence from two surveys 25 years apart. BMJ 1992;304:873-875.

7 Leung R, Ho P: Asthma, allergy and atopy in three south-east Asian populations. Thorax 1994;49:1205-1210.

8 National Population Commission (Nigeria) 2000: Nigeria Demographic and Health Survey 1999. Calverton, National Population Commission and ORC/Macro.

9 ISAAC Co-Ordinating Committee: Manual for the International Study of Asthma and Allergies in Childhood (ISAAC). Bonchum and Auckland, ISAAC Co-Ordinating Committee 1992.
10 Shaw RA, Crane J, Pearce N, Burgess CD, Bremner P, Woodman K, Beasley R: Comparison of a video questionnaire with the IUATLD written questionnaire for measuring asthma prevalence. Clin Exp Allergy 1992;22:561568.

11 Brunekreef B, Groot B, Rijcken B, Hoek G, Steenbekkers A, de Boer A: Reproducibility of childhood respiratory symptom questions. Eur Respir J 1992;5:930-935.

12 Worldwide variations in the prevalence of asthma symptoms: The International Study of Asthma and Allergies in Childhood (ISAAC). Eur Respir J 1998;12:315-335.

13 Martinez F: Role of viral infections in the inception of asthma and allergies during childhood: Could they be protective? Thorax 1994; 49:1189-1191.

14 Matricardi PM, Rosmini F, Riondino S, Fortini M, Ferrigno L, Rapicetta M, Bonini S: Exposure to foodborne and orofecal microbes versus airborne viruses in relation to atopy and allergic asthma: Epidemiological study. BMJ 2000;320:412-417.

15 Ellwood P, Asher MI, Björkstén B, Burr M, Pearce N, Robertson CF: Diet and asthma, allergic rhinoconjunctivitis and atopic eczema symptom prevalence: An ecological analysis of the International Study of Asthma and Allergies in Childhood (ISAAC) data. ISAAC Phase One Study Group. Eur Respir J 2001;17:436443.

16 Strachan DP: Epidemiology; in Silverman M (ed): Childhood Asthma and Other Wheezing Disorders. London, Chapman \& Hall, 1995, pp 7-31.
17 Strachan D, Sibbald B, Weiland S, Ait-Khaled N, Anabwani G, Anderson HR, Asher MI, Beasley R, Björkstén B, Burr M, Clayton T, Crane J, Ellwood P, Keil U, Lai C, Mallol J, Martinez F, Mitchell E, Montefort S, Pearce N, Robertson C, Shah J, Stewart A, von Mutius E, Williams $\mathrm{H}$ : Worldwide variations in prevalence of symptoms of allergic rhinoconjunctivitis in children: The International Study of Asthma and Allergies in Childhood (ISAAC). Pediatr Allergy Immunol 1997;8:161-176.

18 Williams HC, Burney PG, Pembroke AC, Hay RJ: Validation of the U.K. diagnostic criteria for atopic dermatitis in a population setting. U.K. Diagnostic Criteria for Atopic Dermatitis Working Party. Br J Dermatol 1996;135:1217.

19 Popescu CM, Popescu R, Williams HC, Forsea D: Community validation of the UK diagnostic criteria for atopic dermatitis in Romanian school-children. Br J Dermatol 1998;138:436442.

20 Williams H, Robertson C, Stewart A, AitKhaled N, Anabwani G, Anderson R, Asher I, Beasley R, Björkstén B, Burr M, Clayton T, Crane J, Ellwood P, Keil U, Lai C, Mallol J, Martinez F, Mitchell E, Montefort S, Pearce N, Shah J, Sibbald B, Strachan D, von Mutius E, Weiland SK: Worldwide variations in the prevalence of symptoms of atopic eczema in the International Study of Asthma and allergies in Childhood. J Allergy Clin Immunol 1999;103: 125-138.

21 Linna O, Kokkonen J, Lukin M: A 10-year prognosis for childhood allergic rhinitis. Acta Paediatr 1992;81:100-102. 